His first love was political theory, everything from Plato to the moderns. Although he was rather less than enamored with the medieval period, Augustine and Thomas Aquinas demanded his respect, if not his admiration. His second love, American constitutional history and law, was a constant source of concern and object of study for him, although he had an abiding belief that students of the law should, first and foremost, be students of political philosophy.

Jerry was born in Topeka, Kansas, on March 1, 1925. He graduated from Topeka High School in 1943. Soon thereafter, he was inducted into the United States Army, and later served (eventually as a platoon sergeant) in the 103rd Infantry Division, serving in France, Germany, and Austria during 1944-45. He earned a Silver Star for gallantry in action after rescuing wounded comrades from a minefield, a Bronze Star, and a combat infantry badge. Jerry's military service placed an indelible stamp on his personality. In combat, Jerry learned that to be tested under fire was an experience that no person should have to confront, but when so tested, a person must respond with both fear and fortitude. Those experiences brought forth Jerry's courage, leadership abilities, self-discipline, and personal integrity; he proved himself to be a soldier others could trust, respect, and count on in times of terrible danger.

After the war, Jerry studied at Yale University and later received a B.A. and M.A. from the University of Colorado, where he was inducted into Phi Beta Kappa. Subsequently, he was employed for a few years with the U.S. Public Health Service in Washington, DC, and with the Division of Hospital and Medical Facilities. Jerry was much impressed by these bureaucratic experiences and he maintained a continuing interest and involvement in public health policies and programs. Later, he did consulting work with the Colorado Blue Cross, the Colorado Hospital Association, and the Iowa Hospital Association. Jerry also became a member of the Iowa Comprehensive Health Planning Council and a board member of the Iowa Regional Medical Program.

Jerry joined the faculty of Iowa State's then-department of history, government, and philosophy in 1967 . He taught for 28 years in that department (which became the department of political science in 1970), and achieved emeritus status in 1995. His publication record was not substantial, but one could believe (as we do) that few, if any, of us were his equals in the classroom. Twice, the students confirmed that belief by bestowing on him the "Outstanding Teacher" award. He not only knew the material and the fundamental issues of his subjects, he also was able to stimulate students to think. His true greatness as a teacher, however, lay in his ability to touch lives. Many former students years later remember how his care and concern enriched them and shaped their futures. Often-perhaps too often, some of us speculate-he was constructively involved with college and university organizations and committees. His humanist predilections were deep-seated and manifested themselves often in offcampus responsibilities like his membership on the Iowa Humanities Board and eight years of service on its Project Review Committee.

Jerry's immediate family is his wife, Emmy; daughter, Katherine of Gainesville, Florida; and son, Thomas of Chicago, Illinois. A memorial service was held for Jerry in the Memorial Union of Iowa State University on January 15 . Several hundred of those who admired, loved, and greatly respected him came to let him know that he will long be remembered as one of the very best.

Ross Talbot

Iowa State University Richard Mansbach Iowa State University James McCormick

Iowa State University Jorgen Rasmussen

Iowa State University

Dana Schumacher

Iowa State University Mack Shelley

Iowa State University

\section{Henry A. Turner}

On August 1, 1998, Henry A. Turner, professor emeritus of political science at the University of California, Santa Barbara, died after a lengthy illness. He was 79 years of age.

Born in 1919, Henry received his undergraduate education at Northwest Missouri State College, then obtained a master's degree from the University of Missouri in 1941. The following year, he joined the United States Navy and served as an officer on submarine chasers near the Aleutian Islands and a destroyer in the North Atlantic. After the war, he resumed his graduate studies at the University of Chicago and received his Ph.D. in 1950.

In 1948, Henry accepted an appointment at the University of California's small campus in Santa Barbara. At that time, the faculty in the social sciences (which included history and philosophy) were grouped in a social sciences department with some 22 faculty members. With growth, these disparate areas became separate departments. In 1960, Henry Turner became the first chair the department of political science. His colleagues often sought his counsel on matters of policy and appointments. He was instrumental in attracting such well-established political scientists as William Ebenstein and C. Herman Pritchett to teach at UCSB, initially on a visiting basis, then later as regular faculty.

In 1962, the department was authorized to grant the Ph.D. degree. The first two doctorates awarded-in 1964 and 1965-were awarded to students advised by Henry. Each of these students won the "Best Dissertation" prize awarded by the Western Political Science Association. This was a reflection of their mentor's close attention to detail and of the preparation the students received in Henry's graduate seminars, which demanded extensive knowledge of the literature and encouraged pursuit of individual research interests. One of those early doctoral students remembered Professor Turner as a "truly honorable man of impeccable integrity," whose "commitment to excellence for himself 
and his students was central to his character." Another former student fondly recalled that his first seminar with Professor Turner shifted the entire focus of his graduate program by "instilling in me a lifelong joy in studying American politics and public policy. He engaged students in thought-provoking discussions-one mark of an outstanding teacher."

Henry Turner's research and writings centered on American politics and included some two dozen articles and several books, including coauthorship of American Democracy in World Perspective, which went through five editions.

This academic record won Henry recognition in the form of awards from the Ford Foundation, the Rockefeller Foundation, and the American Philosophical Society. In 1962-63, he taught at the University of Khartoum in Sudan. On Fulbright grants, he taught in 1968 at Witwatersrand University in Johannesburg, South Africa; and in 1974, at Tehran University in Iran, under a grant from the U.S. State Department. He also taught summer session courses at the Universities of Missouri, Nebraska, and California, Berkeley. Beginning in 1966, he was listed in every edition of Who's Who in America.

Also notable was Henry Turner's participation in university governance. He was the first UCSB faculty member to serve on the Editorial Board of the University of California Press, being twice appointed to that body. He also served on several UCSB Academic Senate committees, including the important Committee on Academic Personnel, which he chaired in his third and final year. This led to his appointment for two years (1971-73) as acting vice chancellor for Academic Affairs.

Heart surgery in 1974, during which he received blood tainted by the hepatitis- $C$ virus, caused increasing health problems. Nevertheless, he continued teaching on a phasedretirement basis until 1987, when he officially retired from UCSB after 39 years of service. That same year, he was selected as Alumnus of the Year at Northwest University in Missouri.
Henry Turner is survived by his devoted wife of fifty-five years, Mary, as well as by three grown children and seven grandchildren. His family and many friends will remember him especially for his dedication, integrity, fairness, and consideration for others.

Gordon E. Baker
University of California, Santa Barbara
Robert Casier
University of California, Santa Barbara
Stephen Wiener
University of Califomia, Santa Barbara

\section{Marcia Lynn Whicker}

Marcia Lynn Whicker, chair of the graduate department of public administration at Rutgers University, Newark died on March 23, 1999 , after a long battle with cancer. She was only 51 . She came to RutgersNewark in 1992, after having taught at Virginia Commonwealth University, the University of South Carolina, Temple University, and Wayne State University. She received an M.P.A. from the University of Tennessee, an M.S. in economics from the University of Kentucky, and her Ph.D. in political science from the University of Kentucky in 1976. She was an APSA Congressional Fellow in 1975. Since becoming department chair at Rutgers-Newark in 1994, she devoted much of her time and energy to administrative duties and accomplished a great deal in a relatively short time.

Throughout her academic career, Marcia had a deep commitment to teaching and to her students. She spent untold hours mentoring her graduate students and working closely with them to ensure their success. She often collaborated with her students on papers and articles. Shortly before her death, when she was told that the department wanted to honor her in some way, Marcia supported the idea of a scholarship fund in her name for M.P.A. students at Rutgers. This has now been established by the department.

Marcia had a deep commitment to research and was a prolific scholar. She authored, coauthored, or edited sixteen books, published 40 peer-reviewed articles and thirty book chapters, and wrote many other articles and papers. Her research reflected the great breadth of her interests, but it had several central themes. She described two of them as the impact of government structures on policy outputs, using both simulations and real world settings, and leadership, resulting in books on both the presidency and state legislative leaders.

During her years as a graduate student at the University of Kentucky, we found that she was full of thoughtful and perceptive questions, curious about almost everything, and quick to absorb information about things she knew little about. Her curiosity and love of exploring new ideas were lifelong characteristics. Marcia wanted to know everything, especially about how things work, and in the course of trying to find out she would literally devour huge literatures. Then she would try to integrate what she knew and think about what she didn't know, and try to figure out how to maximize the former and minimize the latter. Her first instinct was to resist imposing limits and constraints on inquiry, to try to swallow very large subjects rather than chewing on them bit by bit. This may have helped account for her devotion to simulation as a conceptual tool, which allowed her to rearrange things in ways that the real world was too limited to permit. For her, the intellectual thrill was in seeing the big picture; writing it down was a boring chore. She was incredibly enthusiastic about whatever set of ideas occupied her at a given time, and was endlessly involved in organizing projects, recruiting collaborators, finding book publishers. And then she would move along to other things.

Marcia made friends widely and took pains to maintain contact long after she left an institution or a coauthorship was completed. The advent of email was a great boon to Marcia's nurturing of friendships. Sometimes, her messages were devoted to political science, but they could just as easily be about politics, films, pop psychology, you name it. It was not unusual to communicate 